\title{
El chino homófono: \\ una breve introducción a la enseñanza del fenómeno homófono del chino mandarín
}

DOI: $10.32870 /$ mycp.v2i5.412

Chen $\mathrm{Hao}^{1}$

\section{Resumen}

Este trabajo se enfoca principalmente en el fenómeno homófono del chino, 同音词 (tóng yīn cí), con el objetivo de ofrecer una ayuda a los alumnos del chino mandarín para que lo conozcan, y al mismo tiempo a los maestros para que lo tengan en cuenta y lo utilicen en la enseñanza del chino mandarín. En el presente también se incluyen algunos ejemplos, tanto literarios como coloquiales, de ese fenómeno. De esta manera se reitera el buen funcionamiento cotidiano de este idioma.

Palabras clave: chino mandarín, el fenómeno homófono, enseñanzaaprendizaje del chino.

\section{Abstract}

Above all, the present work focuses on the homophony in Chinese language, 同音词 (tóng yīn cí), which offers a helpful subject for the Chinese language students to study on; meanwhile, for the teachers to take awareness of the homophony teaching in their Chinese teaching class. In this work some exam-

Artículo recibido el 31 de mayo de 2013 y dictaminado el 24 de junio de 2013.

1. Universidad de Estudios Internacionales de Shangai. Correo electrónico: shaertchen@gmail.com 
ples will be introduced. Such examples will be found in the literatures and daily conversations. Thus this will stress the performance of Chinese language.

Keywords: Chinese language, homophonic phenomenon, Chinese teaching and learning.

\section{Introducción}

El gran desarrollo de la economía de China en los últimos años ha intrigado a muchos estudiosos extranjeros, y por ende, el aprendizaje del chino mandarín ha venido cobrando un interés casi febril para los mexicanos. Hoy en día los extranjeros tienen cada vez más curiosidad por decodificar el enigma tanto detrás del desarrollo de la economía, como de la cultura milenaria que han tenido los chinos. Debido a esto, ha surgido una necesidad tajante y pujante del aprendizaje del chino mandarín, que aunque se considera una lengua bastante difícil, vale la pena aprenderla. Los académicos, quienes han invertido gran esfuerzo en sus investigaciones y estudios de las situaciones actuales en China, están también muy entusiasmados por el aprendizaje del idioma mismo, ya que es un instrumento directo e imprescindible para el conocimiento del país. Ellos quieren descifrar, por ende, cuáles son los secretos que los chinos han escondido detrás del mercado.

Con este antecedente, se presentan en este artículo algunos conocimientos fundamentales del idioma chino, tomando como una realidad innegable el fenómeno homófono que posee la lengua. Tanto en el comienzo del aprendizaje del chino como en el nivel avanzado del mismo, los alumnos tienen que estar muy conscientes de este fenómeno. El presente trabajo pretende ser una breve explicación del fenómeno antes mencionado, contando con algunas recomendaciones para aplicarse en la enseñanza del mandarín y así convertirse en una orientación consultable para los maestros del chino mandarín, ya que más adelante ellos podrán utilizar en sus clases algunos de los ejemplos citados.

El fenómeno homófono trata de que dos o más palabras, aunque poseen diferentes formas y significados, tienen la misma pronunciación, lo cual puede observarse en cualquier idioma, como por ejemplo: en inglés tenemos este grupo de palabras: right (correcto), write (escribir), wright (artesano), rite (rito), etc.; en alemán: leib (cuerpo), laib (queso seco), etc.; en francés: balle (pelota), bal (danza), entre otras; en castellano: casa y caza (por cuestión del seseo), bello y vello, tuvo y tubo, etc.; y por último en chino mandarín también existen muchas palabras homófonas: 报复 (/bào fù/vengarse o vengarse de), 
y抱负 (/bào fù²/ambición), 节俭 (/jié jiăn/ahorrar) y 节减 (/jié jiăn/reducir), etcétera.

\section{Origen del fenómeno homófono del mandarín}

Aparte de la homonimia ${ }^{3}$ castellana que se deriva de diferentes orígenes según la lingüistica estructural (Adrados, 1980), la génesis del fenómeno homófono del mandarín también consiste en algunos aspectos que se produjeron durante la evolución idiomática del chino. La razón más radical de la existencia de este fenómeno ha sido que en un idioma no existen suficientes unidades fonéticas o silábicas de sujetos para poder corresponderse con sus significados, que incluso son muchos más. En cuanto al proceso evolutivo del chino mandarín, en la opinión de 孔昭琪 ${ }^{4}$ (Kǒng Zhāoqí, 1991) deben tomarse en cuenta otros orígenes:

\section{- El resultado de la evolución fonética del chino}

En el chino antiguo muchas palabras llevaban pronunciaciones muy distintas; sin embargo, por motivo del desarrollo idiomático se han vuelto iguales en lo referente al fonema. Ejemplos: 公事 (/gōng shì/rutinas), 公式 (/gōng shì/ fórmula), 工事 (/gōng shì/obra de fortificación), 攻势 (/gōng shì/el estado ofensivo). Entre éstos, en el chino antiguo las consonantes de 式 (shì) y 势 (shì) se pronunciaban ligeros; al contrario, la de事 (shì) era un sonoro, y los tres caracteres no compartían ni el lugar ni el modo de articulación, conduciendo esto a un resultado en el que se les atribuían diferentes tonos al pronunciarse. Sin embargo, en el chino mandarín moderno se pronuncian igual. Ejemplos parecidos son: 精力 (/jīng lì/energía) y 经历 (/jīng lì/experiencia); 前程 (/qián chéng/futuro expectativo) y 虔诚 (/qián chéng/devoción); 修养 (/xiū yăng/ cultivación moral) y 休养 (/xiū yăng/holganza), etcétera.

2. En chino, los homófonos principalmente existen en los caracteres porque el拼音 (/pin yìn/el deletreo) solamente lo utilizan para facilitar la pronunciación de ellos mismos.

3. De acuerdo con el autor, la homofonía (el fenómeno homófono) forma parte de la homonimia, que también existe en el mandarín; sin embargo, en el presente no se va a estudiar.

4. Maestro de las letras chinas, licenciado en las letras chinas del Colegio Normal de Shangdong en el año 1962. 
- La escisión de sentido de una unidad en diferentes contextos

De este origen provienen unas palabras homónimas que forman parte de los tres orígenes (Adrados, 1980: 802) de la homonimia castellana.

\section{- Préstamos de otros idiomas}

La transcripción fonética de las palabras prestadas de otros idiomas también ha afectado mucho la formación de las palabras homófonas. Por ejemplo, el carácter 米 $^{1}$ (/mǐ/del inglés metre) tiene diferente significado a * $^{2}$ (/mǐ/arroz), y los dos son palabras homónimas. ${ }^{5}$ En este caso también se encuentran palabras homófonas; ejemplos: 智利 (/zhì lì/transcripción fonética de Chile), 智力 (/ zhì lì/inteligencia) y 致力 (/zhì lì/dedicarse); 中止 (/zhōng zhǐ/interrumpir, préstamo del japonés) y 终止 (/zhōng zhǐ/finalizar o finalizarse), etcétera.

\section{- Simplificación de los caracteres chinos}

La reforma de la escritura china fue impulsada en la segunda mitad del siglo $\mathrm{xx}$ (Pan Lien-Tan, 2005); de allí se transcribieron algunos caracteres tradicionales en los simplificados, lo cual dio lugar a la formación de muchos fenómenos homónimos. Un ejemplo: 錶 (biăo) se transcribió en 表 (biăo), y se generó a su vez el par de仪表 ${ }^{1}$ (/yí biăo/ la apariencia de una persona) e 仪表 ${ }^{2}$ (/yí biăo/instrumento para medir).

\section{- Coexistencia entre los términos propios y los ordinarios}

La invención de algunos términos propios ha producido, de una manera inconsciente, algunos fenómenos homófonos. Tomamos como ejemplos unos pares de palabras lingüísticas al respecto: 音素 (/yīn sù/fono), 因素 (/yīn sù/ factor) y 音速(/yīn sù/velocidad del sonido); 音位 (/yīn wèi/fonema) y 因为 (/yīn wèi/porque, como); 助词 (/zhù cí/palabras auxiliares) y 祝词 (/zhù cí/ palabras de buen deseo), etcétera.

5. No es difícil reconocer que restringiéndose a cierta sílaba singular del 拼音 (pīn yīn) pueden encontrarse muchos caracteres chinos, por eso todos los caracteres son a su vez palabras homónimas, y en el presente trabajo se tratan principalmente las palabras que por lo menos tienen dos sílabas, de donde proviene la ambigüedad del uso y también el fenómeno homófono. 
- Abreviación de las palabras

Como no ha habido una norma estricta para la abreviación de los caracteres chinos, sea por el uso coloquial o por la subjetividad de la gente, la abreviatura de algunas palabras ha sido convencional y versátil, de este modo aparecen las palabras homófonas: 机校 (/jī xiào/escuela de mecanismo), abreviatura de 机械学校 (/jī xiè xué xiào/escuela de mecanismo), y 讱笑 (/jī xiào/reírse, con indiferencia, de alguien) que es una palabra hecha; 业大 (/yè dà/colegio para quienes ya tienen trabajo), abreviatura de 业余大学 (/yè yú dà xué/colegio para quienes ya tienen trabajo), y 夜大 (/yè dà/colegio nocturno), abreviatura de 夜晚的大学 (/yè wăn de dà xué/el colegio de noche), etcétera.

Como se ha señalado, en el presente trabajo se habla de las palabras homófonas que llevan por lo menos dos sílabas, debido a que las de una sílaba, como en el caso del 米, no son difíciles de clarificar en su significado dentro de un contexto, es decir, no llegan a producir tantas confusiones como las de dos o más sílabas, que pueden causar ridiculeces y algunos chistes muy graciosos o, a la vez, el doble sentido en el uso estilístico.

\section{Homofonía en la estilística literaria del idioma chino}

La existencia del fenómeno homófono de un idioma, sin duda alguna puede causar algunas inconveniencias en la comunicación diaria, porque en una conversación, el receptor podrá malinterpretar lo que quiere decir el emisor; aquí puede suceder lo que se denomina "ambigüedad". No obstante, el aprovechamiento y buen uso del fenómeno homófono también se ha encontrado a lo largo de la historia en algunas obras literarias de autores conocidos, quienes han utilizado ingeniosamente el funcionamiento de la "idiosincrasia ambigua" que tiene la homofonía, destacando a su manera un toque sarcástico e irónico de su escritura. He aquí un ejemplo en el Buscón, de Quevedo:

La bercera (que siempre son desvergonzadas) empezó a dar voces; llegáronse otras y con ellas pícaros, y alzando zanorias, garrofales, nabos frisones, tronchos, y otras legumbres, empiezan a dar tras el pobre rey. Yo viendo que era batalla nabal y que no se había de hacer a caballo, comencé a apearme; mas tal golpe me le dieron al caballo en la cara que, yendo a empinarse, cayó conmigo en una (hablando con perdón) privada (Quevedo, 1631: 6). 
El fenómeno homófono de nabal puede percibirse fácilmente en la lectura y también uno puede captar un matiz gracioso en cuanto a considerar que una batalla de nabos sería como una batalla entre naves marítimas,

La existencia del fenómeno homófono de un idioma, sin duda alguna puede causar algunas inconveniencias en la comunicación diaria, porque en una conversación, el receptor podrá malinterpretar lo que quiere decir el emisor; aquí puede suceder lo que se denomina "ambigüedad". No obstante, el aprovechamiento y buen uso del fenómeno homófono también se ha encontrado a lo largo de la historia en algunas obras literarias de autores conocidos, quienes han utilizado ingeniosamente el funcionamiento de la "idiosincrasia ambigua" que tiene la homofonía, destacando a su manera un toque sarcástico e irónico de su escritura así que no cuesta mucho trabajo imaginar la escena tan violenta y enconada que pueda tener esta batalla y el desenlace tan desastroso que pueda resultar.

En algunos poemas de la antigua China puede notarse, como en el caso del castellano, la habilidad de los poetas en el uso homófono, que ha sido denominado como 双关 ${ }^{6}$ (/shuāng guān/dilogía del chino). Éste se verá en 《竹枝词之一》(uno de dos cantos de Zhúzhīi) ${ }^{7}$ de 刘 禹锡 (Liú Yǔxī): ${ }^{8}$

杨柳青青江水平, 闻郎江上 踏歌声。

Yáng liǔ qīng qīng jiāng shuǐ píng, wén láng jiāng shàng tà gè shēng.

[Los sauces verdosos, el río quieto, en un barco, cantaba un mozo.]

东边日出西边雨, 道是无晴 却有晴。

Dōng biān rì chū xĩ biān yǔ, dào shì wú qíng què yǒu qíng.

6. Una disciplina retórica de la estilística literaria del chino donde las palabras cuyos significados contextuales o superficiales se encajan perfectamente en el texto, tienen otros sentidos convencionales o más profundos para expresar los conceptos e ideas de una manera más concisa, humorística.

7. Nombre propio del tono de una serie de poemas.

8. Poeta chino, (772-842 D.C.) filósofo, ensayista, de la dinastía Tang, bien conocido por sus poemas folklóricos. 
[En el este, brillaba el sol, en el oeste, caía la lluvia. Decían: si el amor se prendería por la luz o se apagaría por las gotas.]

Como se sabe, los versos son muy difíciles de traducir, y la traducción sería casi imposible cuando unos conllevaran la dilogía (podría decirse como ambigüedades). En la traducción del último verso el autor ha tratado de explicar lo que significa implícitamente, porque el ingenioso poeta utilizó la palabra 晴 (qíng), que significa literalmente que el cielo está muy despejado, sin nubes, para ocultar otro sentido, del que según el contexto uno puede deducir que el canto del joven en el barco se dirigía probablemente a una chica que estaba en la ribera, quien pensaba de una manera dubitativa que si detrás de las letras se escondía su amor o no, porque todavía el mozo no le había declarado su amor. Para ser más explícito, el amor en chino se dice 情 (qíng). De este modo, las palabras 无晴 (/wú qíng/no hace buen tiempo) e 有晴 (/yǒu qíng/hace buen tiempo), le llevan a uno a emparejar con sus palabras homófonas 无情 (/wú qíng/no existe amor) y 有情 (/yǒu qíng/existe amor), y aquí está el buen uso de双关 (/shuāng guān/dilogía del chino) del poeta.

En algunos poemas pueden obtenerse las imágenes tanto de plantas como de otros objetos, entre las cuales algunos poetas las utilizaban para interpretar sus cariños y emociones hacia las personas a quienes ellos extrañaban. Por ejemplo en este verso:

\section{雾露隐芙蓉, 见莲不分明。9}

Wù lù yǐng fū róng, jiàn lián bù fēn míng.

[El hibisco, oculto bajo el rocío, y el loto, vuelto borroso.]

Convencionalmente utilizaban los poetas el 芙蓉 (/fú róng/la flor del hibisco), 莲 (/lián/loto), 藕 (/ǒu/la raíz de loto), 丝 (/sī/la fibra de loto) para referir, respectivamente a la cara de esposo, compasión, pareja, añoranza, porque esas palabras tienen sus homófonas como 夫容 (/fū róng ${ }^{10} /$ la cara de marido), 怜 (/lián/compasión), 偶 (/ǒu/pareja), 思 (/sī/añorar). Y en ese verso, a pesar de que uno puede captar una descripción romántica de la flor del hibisco, puede deducir también que una esposa le estaba echando la culpa a su pareja, quejándose de que su amor había sido como un hibisco escondido detrás de

9. Nombre propio del tono de una serie de poemas.

10. Poeta chino, (772-842 d. C.), filósofo, ensayista, de la dinastía Tang, bien conocido por sus poemas folclóricos. 
una neblina, indeciso e invisible, con que la palabra芙蓉 (/fú róng/la flor del hibisco), interpretada como 夫容 (/fū róng/la cara de marido), y la 见莲 (/ jiàn lián/ver el loto), como 见怜 (/jiàn lián/el amarme) ${ }^{11}$ se hacen explicables.

El uso literario de la ambigüedad puede verse hasta en algunos pseudónimos de autores o de algunos grupos de editores. ${ }^{12}$ La palabra 童怀周 (/tóng huái zhōu/nombre propio) quiere decir 同怀周 (/tóng huái zhōu/conmemorar juntos al primer ministro Zhou), ${ }^{13}$ y la palabra初澜 (/chū lán/nombre propio de un grupo editor) quiere decir 出蓝. (/chū lán/salir del azul), que proviene de la frase hecha青出于蓝 (/qiing chū yu lán/la tintura azul procede de la bistorta y es más azul que esta planta: ${ }^{14}$ el alumno sobresale de su maestro). Por cierto que la aparición de estos nombres se debió al control por el gobierno o por alguna censura mediática; sin embargo, no pierde su encanto idiomático tanto como en las 歇后语 (/xiē hòu yŭ/alegorías chinas), ${ }^{15}$ donde se destaca también el fenómeno homófono y a la vez una inteligencia desdeñable del pueblo chino. He aquí unos ejemplos:

\section{外甥打灯笼一一照旧(舅)。}

Wái shēng dă dēng lóng ------ zhào jiù (jiù).

La primera parte de esta proposición quiere decir el sobrino con una linterna a la mano. Cabe preguntar ¿para qué con una linterna? Después viene la segunda parte, más la palabra 照旧 (zhào jiù), quiere decir como lo anterior. ¿Qué conexo se entrelaza entre las dos partes? El meollo se encuentra en que 舅 (jiù) es la palabra homófona de 旧 (/jiù/pasado, antiguo), que significa tío. De esta manera, cuando alguien dice la primera parte de ese enunciado, los

11. De 《子夜歌》(/zǐ yè gē/Cantos de medianoche), un género poético, uno de los géneros más clásicos de la poesía china.

12. Se conoce que en el chino mandarín las sílabas llevan tonos, en total son cuatro tonos. A veces los tonos se estilizan para llegar a tener un efecto ambiguo, así como el fenómeno homófono, lo cual ha sido denominado como 谐音 (/xié yīn/literalmente, la consonancia), al que pertenece también la homofonía pero en este caso el efecto tónico. De esta manera, como los dos fenómenos están muy liados, dedicaremos un apartado para explicar un poco el efecto de confusión que pueden tener los tonos de nuestro idioma.

13. Aquí el 见怜 aunque tiene un carácter怜, que significa, como se indica unas líneas arriba, compasión, y los dos caracteres juntos: véase la compasión, pero según el contexto, más bien entendemos como el amarme.

14. Se trata de algunos equipos de editores cuyos miembros utilizan el mismo pseudónimo.

15. 周恩来 (Zhōu Ēnlái: 5 de marzo de 1898, Beijing, 8 de enero de 1976): un destacado político de la República Popular China, miembro del Partido Comunista Chino desde su juventud y primer ministro de China desde el establecimiento del régimen comunista en 1949 hasta su muerte. 
otros entienden inmediatamente que él o ella está comentando que hay que seguir como antes.

Las 歇后语 (xiē hòu yŭ) varían en muchos modelos, y aquí se propone el estudio del de la homofonía. Además de que éstas cuentan con palabras de una sola sílaba, como en el caso de舅 (jiù), también están incluidas otras de dos o más sílabas:

1

老公拍扇——凄凉(妻凉)。

Lăo gōng pāi shàn ------ qī liáng (qī liáng).

La primera parte: el marido agita el abanico.

La segunda: 凄凉 (/qī liáng/desolado, triste).

妻凉 (/qī liáng/la esposa se siente fría).

空中布袋——装疯(装风)。

Kōng zhōng bù dài ----- zhuāng fēng (zhuāng fēng).
La primera: el saco que está en el aire.

La segunda: 装疯 (/zhuāng fēng/fingirse loco).

装风 (/zhuāng fēng/meter el viento).

3

二三四五六七八九一一缺衣少食(缺一少十)。

Ėr sān sì wǔ liù qĩ bā jiǔ------quē yĩ shăo shí (quē yī shăo shí)

La primera: dos tres cuatro cinco seis siete ocho nueve.

La segunda: 缺衣少食 (/quē yī shăo shí/faltan ropa y alimento)

缺一少十 (/quē yĩ shăo shí/faltan uno y diez).

En total, en el idioma del mandarín existen más de 25,000 alegorías de 歇 后语, cuyo uso se ha practicado profundamente en la vida cotidiana de los chinos, ora para burlarse de las cosas, ora para explicar algunos conceptos de un modo inteligente y gracioso. Desde luego, el fenómeno homófono forma una parte muy importante dentro de ese ámbito; más aún, ha sido tan significativo que hasta el catedrático 赵元任 (Zhào Yuánrèn) ${ }^{16}$ redactó un cuentito con el chino tradicional para oponerse a la voz de la latinización del

16. 青出于蓝, 而胜于蓝: /qīng chū yú lán, ér shèng yú lán/ la tintura azul procede de la bistota y es más azul que esta planta. Traducido por 赵士钰 Zhào Shìyù, 1935: 12, catedrático de la Universidad de Estudios Internacionales de Beijing (Zhao, 2010: 171). 
chino, planteado por sus coetáneos, con la razón de que el idioma chino lleva muchas palabras homófonas, y porque la latinización de los caracteres, a su vez, generaría muchas similitudes silábicas, así como ambigüedades:

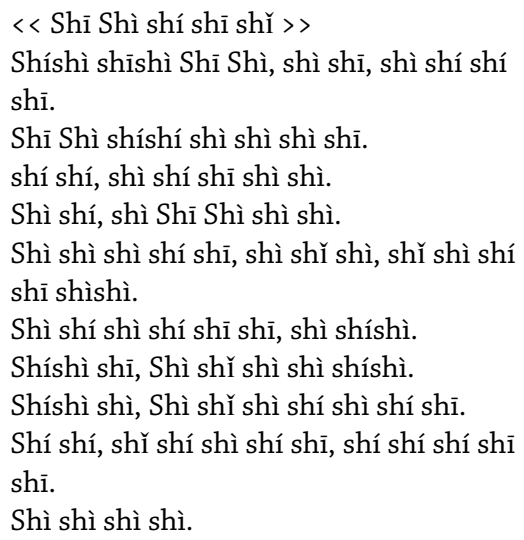

Fuente: de la traducción disponible en: http://www.guioteca.com/cultura-china/por-que-elchino-es-uno-de-los-idiomas-mas-dificiles/

No es difícil saber cuáles son las palabras homófonas de este cuento, que son las siguientes, entre las cuales varía a veces el tono:

\begin{tabular}{lll}
\hline Carácter & Pīnyīn & Significado \\
\hline 石 & Shí & Piedra \\
室 & Shì & Cuarto \\
诗 & Shì & Poema \\
士 & Shì & Persona \\
施 & Shì & Un apellido \\
氏 & Shì & Apellido \\
嗜 & Shì & Gustar \\
\hline
\end{tabular}




\begin{tabular}{|c|c|c|}
\hline Carácter & Pīnyīn & Significado \\
\hline 狮 & Shī & León \\
\hline 十 & Shí & Diez \\
\hline 誓 & Shì & Jurar \\
\hline 食 & Shí & Comer \\
\hline 时 & Shí & Hora, tiempo \\
\hline 适 & Shì & Llegar \\
\hline 市 & Shì & Mercado \\
\hline 视 & Shì & Mirar, ver \\
\hline 是 & Shì & Este, estos \\
\hline 恃 & Shì & Apoyarse por \\
\hline 矢 & Shǐ & Flecha \\
\hline 势 & Shì & Fuerza \\
\hline 使 & Shǐ & Dejar \\
\hline 逝 & Shì & Morir \\
\hline 世 & Shì & El mundo \\
\hline 拾 & Shí & Recoger \\
\hline 尸 & Shī & Cadáver \\
\hline 湿 & Shī & Húmedo \\
\hline 侍 & Shì & Siervo \\
\hline 拭 & Shì & Limpiar \\
\hline 试 & Shì & Intentar \\
\hline 始 & Shǐ & Empezar \\
\hline 识 & Shí & Reconocer \\
\hline 实 & Shí & En realidad \\
\hline 释 & Shì & Explicar \\
\hline 事 & Shì & Cosa \\
\hline
\end{tabular}

Fuente: elaboración propia.

\section{La aplicación del fenómeno homófono en la enseñanza del chino mandarín}

Sería muy interesante que se incluyera el estilo literario de la homofonía del chino en las clases del chino mandarín y podría servir para cautivar con mucho entusiasmo y animación a los alumnos en su aprendizaje, porque se trata de una técnica, un arte, que se acumula en la vida cotidiana, y para ello es necesario el humor. Así se dice, a pesar de que hasta aquí no se ha visto o dado ningún ejemplo como chiste que pueda causar risas a los lectores, sino 
unos casos académicos que vale la pena investigar. Sin embargo, el fenómeno homófono se encuentra tan cerca de la vida cotidiana como el alburear a la manera mexicana en el entretenimiento para los interlocutores o simplemente para animar una conversación insípida, hasta para aliviar el ambiente intenso en la clase.

A los alumnos les cuesta mucho trabajo manejar la pronunciación del chino mandarín, y memorizar el significado de palabras junto con sus sílabas. No obstante, es muy notable que ellos pueden memorizar lo espontáneamente planteado, como por ejemplo: les da mucho gusto saber cómo se dice te amo en chino, y no les sería nada difícil repetirlo con una voz cariñosa Wǒ ài ň̆ (te amo). Obviamente que a esta buena memoria colabora en gran parte el interés, que es muy importante y decisivo en cualquier estudio, y mucho más en el aprendizaje de un idioma.

En una ocasión cuando el autor estaba enseñando a sus alumnos la palabra 问 (/wèn/preguntar), cuya pronunciación es sencilla, y después de explicar lo que significaba, hizo una comparación de las palabras问 (/wèn/preguntar) y 吻 (/wěn/besar) con las dos frases siguientes para impresionarlos más:

\author{
我想问你。 \\ Wǒ xiăng wèn nǐ. \\ (Yo quiero preguntarte.) \\ y \\ 我想吻你。 \\ Wǒ xiăng wěn nǐ. \\ (Yo quiero besarte.)
}

Ellos, al comprender esta comparación, echaron una carcajada, y más tarde, estando muy conscientes de la diferencia que tenían las dos palabras, no las iban a olvidar nunca. El resultado está claro. Los maestros deben prestar mucha atención a las palabras chinas que van a enseñar a los alumnos, y encontrar meticulosamente, como en este caso, palabras homófonas de las palabras nuevas para que los alumnos las memoricen con más facilidad, especialmente en el nivel inicial.

Debe añadirse que los cuatro tonos, como son muy particulares en el idioma chino, se empeñan de un papel inseparable del fenómeno homófono. Los occidentales, como no se acostumbran al discernimiento de las subidas y 
bajadas de los tonos tanto verbalmente como por escrito, podrían confundirse muy fácilmente con ellos, y los ejemplos de desatinos y chistes tónicos les ayudarán a ponerse atentos para no volver a cometer errores, sean molestos o graciosos, los errores en el entendimiento de la comunicación. Otro ejemplo muy clásico del tono:

我在这教书育人。

Wǒ zài zhè jiāo shū yù rén.

(Estoy aquí para educar a la gente.)

y

我在这教书愚人。

Wǒ zài zhè jiāo shū yú rén.

(Estoy aquí para encarnecer a la gente.)

Si uno se equivoca del cuarto tono de la sílaba 育 (/yù/educar) y se dirige a su interlocutor con el segundo tono愚 (/yú/encarnecer), la frase podría causar un malentendido hasta tal punto que los dos puedan concluir la conversación en una pelea.

Semejante situación sucederá también con esta frase: 你能货到付款么? (/Nǐ néng huò dào fù kuăn me? / ¿Aceptas que te pague cuando lleguen las mercancías?) Es una pregunta formulada por un cliente que quiere pagar las mercancías en cuanto éstas le lleguen, y si se equivocan del cuarto tono de la palabra 货 (/huò/mercancías) por el segundo de la palabra 活 (/huó/vivir), sería otro significado en la siguiente frase: 你能活到付款么? (/Nǐ néng huó dào fù kuăn me? / ¿Sigues vivo hasta el momento en que te pague?), que significa "si tú sigues vivo cuando te llegue el pago". Sin lugar a dudas, la última frase es falta de respeto. Así que uno puede darse cuenta de lo importante que son los cuatro tonos del chino mandarín. Lo mismo ocurrirá con el fenómeno homófono, que a veces genera ambigüedades muy graves hasta en la administración de una empresa, si uno no presta suficiente atención al respecto. Como por ejemplo: una vez en una fábrica el encargado de los técnicos descubrió una falla muy grave en la línea de producción y decidió convocar a todos los técnicos en la junta rutinaria del viernes, y como sería muy importante la reunión, quería enfatizar la urgencia del aviso para todos y se le ocurrió poner algunos caracteres en rojo: 周五务须来开会。(/Zhōu wǔ wù xū lái kāi huì./ Hace falta su presencia este viernes.). Sin embargo, se 
equivocó en la palabra 务须 (/wù xū/hace falta) por su palabra homófona 勿 需 (/wù xū/ no hace falta), y la frase salió como 周五勿需来开会。(/Zhōu wŭ wù xū lái kāi huì./ No hace falta su presencia este viernes.) Resultó que con los caracteres en rojo, los técnicos, que eran flojos, se dieron perfecta cuenta (o se aprovecharon de una excusa a propósito) de que no habría ninguna junta de la semana y podrían disfrutar un buen fin de semana tranquilos. Entonces nadie vino a la reunión excepto el encargado, muy enojado y paralizado por su propia culpa.

Tanto los tonos como el fenómeno homófono pueden causar ambigüedades en la comunicación cotidiana, y se trata también de un trabajo arduo para los principiantes en su etapa inicial del aprendizaje del chino mandarín. En 2007 se publicó el 《现代汉语同音词词典》(Diccionario de homofonía del chino moderno), donde se han recopilado más de 7,000 términos de palabras homófonas de por lo menos dos sílabas, los cuales son discutibles pese a ser muy interesantes. Sin embargo, para la enseñanza del chino mandarín como lengua extranjera no hace falta recurrir a todas las palabras homófonas que hay en el diccionario. Con el objetivo de provocar el interés de los alumnos se recomienda utilizar algunos chistes y dichos, como las 歇后语 para obtener cierto objetivo en clases. Por añadidura, parece importante subrayar que los alumnos principiantes tienen que estar muy atentos en cuanto a aprender las pronunciaciones de ciertas sílabas y también cuidar mucho los tonos, lo cual recaerá a cargo de los maestros, quienes podrían tratar de encontrar, en el caso homófono, las palabras semejantes para que sus alumnos muestren mayor interés.

Uno de los métodos que los maestros pueden utilizar en la clase consiste en realizar algunas comparaciones del fenómeno homófono entre el castellano y el chino, es decir, después de que ellos se enteren del concepto de la homofonía, los maestros podrían explicar de una manera más explícita con el apoyo de algunos ejemplos del español, tales como:

- ¿Qué es el arte?

- Morirte de frío.

(El arte tiene un significado de la "interpretación plástica" y el otro, de "helarte".) 
y

Va un enano a comprar mistol a la tienda.

- Oiga, ¿me da un mistol?

- ¿Para la vajilla?

- No, ipa' tu puñetera madre!

(En este chiste existe el betacismo, ya que se escriben diferentes pero se pronuncian igualmente: vajilla y bajilla.)

Luego pasarían por los ejemplos del chino. Si van a explicar lo que significa esta palabra 全部 (/quán bù/todo), que es una palabra fundamental, pueden iniciar con este cuento: hace algunos años en China, el pueblo escuchaba la radio. Fue una vez cuando estaban emitiendo un aviso de un rico, quien en el trance de muerte iba a dictar su testamento y más tarde dijo: "Cuando me muera, 所有的遗产全不给某甲。(/Suǒ yǒu de yí chăn quán bù gěi mǒu jiă./ De todas mis herencias no le dejo nada a ese fulano.)” Este 某甲 (/mǒu jiă/el fulano) también lo oyó al otro lado de la pared. A partir de ese día, empezó a ofrecer al rico un cuidado muy sofisticado hasta cuando éste se murió. Sin embargo, el abogado del rico entregó toda su herencia a un instituto de caridad, dejando nada a este 某甲 (mǒu jiă/el fulano). Como éste tenía muchas dudas de esta operación, fue a preguntar al abogado y entendió que había confundido la palabra 全不 (/quán bù/nada) por 全部 (/quán bù/todo), y había entendido el testamento como 所有的遗产全部给某甲。(/Suǒ yǒu de yí chăn quán bù gěi mǒu jiă./Todas mis herencias las dejo a ese fulano.)

Del mismo modo, si se les ocurre a los maestros la explicación de la unidad毛 (/máo/unidad monetaria, 1 máo = 20 centavos de peso) de la moneda china, se les recomendará contar este chiste: a un joven le gustaba mucho leer, especialmente los libros de una escritora popular que se llamaba 三毛 (/ Sān Máo/pseudónimo de una escritora). ${ }^{17}$ Como quería coleccionar todas las novelas de esta maestra, iba librería por librería a preguntar por sus libros. Cuando entró en una librería, le preguntó al librero: 请问你们这里有三毛的 书吗? (/Qǐng wèn nǐ mén zhè lǐ yǒu sān máo de shū mā?/ Por favor, ¿tienen ustedes libros de San Mao?) El librero de repente se volvió muy enfadado y le respondió: 穷鬼就别逛书店了! (/Qióng guǐ jiù bié guàng shū diàn le!/¡No

17. Una de las cuatro obras clásicas grandiosas de la literatura china. Las otras son: 红楼梦 (/Hóng Lóu Mèng/El sueño del pabellón rojo), 水吘传 (/Shuǐ Hǔ Zhuàn/A la orilla del agua), 三国演义 (/Sān Guó Yăn Yì/Romance de los tres reinos). 
te da vergüenza si no tienes suficiente dinero!). El chiste consiste en que el librero le entendió la palabra 三毛 (/Sān Máo/ pseudónimo de una escritora) por 三毛 (/sān máo/60 centavos de peso). Ésta 三毛 es una palabra homónima, que además de tener confusión en la pronunciación puede también tener ambigüedad en la escritura.

Cuando los profesores traten de explicar 妇女 (/fù nü/mujeres) a sus alumnos, lo más común y lógico será relacionar esta palabra con el día de las mujeres, y lo chistoso puede verse también en la inocencia de una niña quien, cuando regresó el día 8 de marzo a su casa, gritó a su mamá: “¡Mami, vete a preparar unos platillos para papá y para mí!” Y su madre le repuso muy confundida: "pero por qué, ¿de quién es el día de hoy?" La niña se rió, con plena razón: “三八父女节, 是我跟爸爸的节日! (/Sān Bā Fù Nü Jié, shì wǒ gēn bà ba de jié rì./jEl 8 de marzo es el día de papá y de mí!)” Como se ve, La niña cometió un error homófono y malentendió la palabra 妇女 (/fù nü/mujeres) por 父女 (/fù nü/padre e hija).

La comparación del fenómeno homófono entre el castellano y el chino se hace para que los alumnos manejen mejor, y de una manera graciosa, las palabras chinas que van a aprender. Sin embargo, no todas las palabras tienen sus semejantes homófonos, a pesar de que los idiomas los tengan como una característica evolutiva y renovadora por su uso cotidiano. Como se ha mencionado, los maestros pueden despertar el interés de los alumnos para mostrarles algunos ejemplos del tono y la homofonía del chino; también lo pueden efectuar para infundirles la importancia que tiene la pronunciación del chino mandarín. Los ejemplos son muchos al respecto:

1. En 《西游记》 (/Xī Yóu Jì/Viaje al oeste), ${ }^{18}$ el emperador dice a 唐僧 (/ Táng Sēng/nombre propio que significa el monje de la dinastía Tang): ${ }^{19}$ "Carnal, por el camino habrá muchísimos monstruos que te van a hacer daño, pues te doy un arma mágica, 你可以用它来收妖。(/Nǐ kě yǐ yòng tā lái shōu yāo./Puedes usarla para matar a los monstruos.)" Al decir eso, el emperador recibe un traje del séquito y dice: “这件小西服, 收腰的。

18. En el Viaje al oeste, fue adaptado de 玄牀 (/Xuan Zang/nombre propio) (602-664), fue un célebre monje budista chino Ch'an, nacido en Luoyang (Henan) en el seno de una familia de eruditos.

19. En el Viaje al oeste, fue adaptado de 玄牀 (/Xuan Zang/nombre propio), (602 - 664) fue un célebre monje budista chino Ch'an, nacido en Luoyang (Henan) en el seno de una familia de eruditos. 
(/Zhè jiàn xiăo xĩ fú, shōu yāo de./Este esmoquin es para que te veas bien figurado de la cintura.")

El chiste se encuentra en las dos palabras homófonas: 收妖 (/shōu yāo/matar a los monstruos) y 收腰 (/shōu yāo/desgrasar la cintura).

2. Había una vez un soldado que perdió una batalla y cayó en manos de sus enemigos. El general enemigo le torturaba para que el pobre confesara y le preguntó: “报出你老大的名字, 我可以饶你不死! (/Bào chū nǐ lăo dà de míng zì, wǒ kě yǐ ráo nǐ bù sǐ!/ ¡Denuncia el nombre de tu jefe y te dejo en libertad!)" Y el soldado contestó con bastante dificultad: 倪 差想! (/Ní Xiūxiăng/nombre propio). Pero le castigaron con la muerte inmediatamente.

El chiste existe en el tono y la homofonía de las palabras: 倪羞想 (/Ní Xiūxiăng/nombre propio) y 你休想 (/nǐ xiū xiăng/ni hablar), y ésta la entendió el general.

3. Había una vez un maestro que tuvo un accidente de tráfico y estaba en el hospital. Un periodista iba a entrevistarle, por eso el maestro les marcó a sus alumnos para decirles: “你们记得穿校服, 带上花。(/Nǐ mén jì de chuān xiào fú, dài shàng huā./ Recuerden venir con uniformes escolares y traigan flores.)” Más tarde llegaron sus alumnos, 穿着孝服, 带着花 圈。(/Chuān zhe xiào fú, dài zhe huā quān./Se vestían de luto y llevaban coronas funerarias) llorando muy tristes.

El chiste está en que los alumnos entiendan el uso de la palabra 校服 (/xiào fú/uniformes escolares) por 孝服 (/xiào fú/trajes de luto).

El fenómeno homófono también se considera como un tema fundamental y complicado para los chinos, y muchas veces por ello tienen que considerarlo con mucho esmero para no cometer errores o convertir su conversación en algo chistoso para sus oyentes. Si no se presta atención a los casos homófonos en la conversación, la situación sería como un occidental que sale a caminar por la calle, vestido en una t-shirt con un carácter chino encima sin saber lo que significa, pero que en realidad significa algo divertido, hasta pervertido para el entendimiento de los chinos y éstos se ríen sin que él mismo se dé cuenta. Para evitar esta situación como 言者无心, 听者有意。(/Yán zhě wú xīn, tīng zhě yǒu yì./El emisor no tiene mala intención en cuanto a hablar pero el receptor lo entiende a su antojo. O sea, el sordo no oye, pero bien que 
compone.) Los maestros tienen que advertir a sus alumnos de la necesidad de manejar, con lo que puedan, la pronunciación del chino y pedirles que se den cuenta también de la naturaleza cambiante de tonos y de las sílabas del idioma chino.

\section{Conclusión}

Como se ha indicado anteriormente en otros apartados, este artículo se limita a introducir brevemente al fenómeno homófono del chino mandarín, lo cual puede ser de gran ayuda tanto para los alumnos principiantes en el aprendizaje del chino como para los avanzados, con el objetivo de que los principiantes lo lean para tener conciencia de su etapa básica del estudio fonético y la escritura del Pīn Yìn, mientras que los avanzados puedan obtener una idea un poco más completa de lo que tratan la homofonía del chino y la característica variable de los tonos que posee el idioma; al mismo tiempo, para tratar de evitar los errores fonéticos y gramaticales que son fáciles de cometer en la comunicación cotidiana.

Para los nativos de la lengua china, claro está que existen varias soluciones en cuanto a las ambigüedades que puedan generar esos fenómenos, que diariamente surgen inconscientemente en los coloquios circunstanciales.

Las medidas que se pueden aplicar consisten principalmente en la sustitución léxica para las palabras homófonas. Como por ejemplo, se puede sustituir la palabra 期终 (/qí zhōng/el final de un periodo) por 期末 (/qí mò/el final de un periodo) para que no se confunda con la 期中 (/qí zhōng/ la mitad de un periodo); así, la 试场 (/shì chăng/el sitio de examen) por 考 场 (/kao chang/el sitio de examen) para no meterse en un lío con 市场 (/shì chăng/el mercado), y 水道 (/shuǐ dào/camino por el agua) por 水路 (/shuǐ lù/ camino por el agua), para estar completamente ajena al significado de 水 稻 (/shuǐ dào/el arroz). Aparte de esta manera de eliminar la ambigüedad, es muy recomendable añadir un carácter para formar una palabra de dos sílabas, como a 向钱看 (/xiàng qián kàn/sólo mirar el dinero), se le añade un carácter 金 (/jīn/oro, dinero) para convertirla en 向金钱看 (/xiàng jīn qián kàn/sólo actuar por el dinero) y de este modo sería distinguible de la palabra 向前看 (/xiàng qián kàn/mirar hacia adelante).

Estas reglas han sido tomadas para controlar un poco las consecuencias negativas del fenómeno homófono; sin embargo, todos saben que los idiomas evolucionan. En el periodo del aprendizaje de las palabras o de léxicos nuevos, 
es muy recomendable que los maestros busquen las palabras homófonas y algunos ejemplos como los anteriormente tratados, porque así sería fácil organizar algunos ejemplos con palabras ambiguas pero interesantes. De todos modos, se requiere que los estudiantes del chino mandarín conozcan ese fenómeno y estén más atentos a su uso; a los maestros se les invita a aprovechar lo ventajoso de ese fenómeno y aplicarlo en sus clases para sus futuros logros educativos del idioma y esquivar los casos indecisos y confusos de la enseñanza de las palabras.

\section{Referencias bibliográficas}

Adrados, F. R. (1980), Lingüistica estructural, Madrid: Gredos.

Chen, H. (2013), Análisis de la homonimia léxica del español y la investigación en su enseñanza de ele, Shangai: Universidad de Estudios Internacionales de Shangai.

Gu, Y. (1981), “《汉语拼音词汇》 同音词再统计 [Nueva estadística de la homofonía de las palabras homofonas del chino]”, 《语文研究》 [Revista Investigaciones de las Letras Chinas], 2(1), pp. 99 y 100.

Kong, S. Q. (1991), “论现代汉语同音词 [Sobre las palabras homófonas del chino moderno]”, 山东师大学报 [Revista de la Universidad Normal de Shangdong], núm. 1, pp. 87-91.

Li, T., y Li, X. J. (2005), “现代汉语同音词误用的原因及倾向 [La razón e inclinación del mal uso de las palabras homófonas del chino moderno]", 黑龙江教育学院学报 [Revista del Colegio de Educación de Hei Longjiang], 24(4), pp. 58-60.

Liu, C. (1995), “汉语同音词的产生及来源 [El origen de las palabras homófonas del chino]”, 内蒙古民族师院学报 [Revista de la Universidad de Nacionalidad de la Mongolia Interior], 64(4), pp. 68-70.

Pan, L. T. (2005), "La reforma de la escritura china: La simplificación", Estudios de Asia y África, xL(2), mayo-agosto, México: El Colegio de México, pp. 445-464.

Pang, L. L. (1986), “英汉同音词比较 [Comparación de las palabras homofónas entre el inglés y el chino]”, 广西民族学院学报 [Revista de la Universidad de Nacionalidades de Guang Xi], núm. 4, pp. 150-156.

Quevedo, F. (1631), Historia de la vida del buscón llamado don Pablos, ejemplo de vagamundos y espejo de tacaños, Pamplona: Reino de Navarra. 
Wu, Z. P. (1993), “现代汉语同音词自动分化系统简介 [Breve introducción del sistema de auto-diferenciación de las palabras homofónas del chino moderno]", 《语言研究》 [Revista de la Investigación de Idiomas], 25(2), pp. 198 y 199.

Zhang, B. (2004), “现代汉语同形同音词与多义词的区分原则和方法 [Las maneras para distinguir las palabras homónimas de las polisémicas del chino moderno]", 语言教学与研究 [Revista La Investigación y la Enseñanza de Idiomas], núm. 4, pp. 36-45.

Zhao, S. Y. (2010), Nuevo curso de traducción del chino al español, Beijing: Prensa de Educación e Investigación de Idiomas Extranjeros.

\section{Fuentes electrónicas}

Jin, Xiao Fang (2012), “谈谈古诗的谐音双关 [Sobre la dilogía armónica de la poesía antigua]”, El escritorio de Jin Xiaofang, octubre 23, disponible en: http://www.jxteacher.com/jinxiaofang/column30271/c4fbc624-b1034115-981e-2485dd556d65.html

Kang, Jin Sheng (2003), “谐音双关：诗“兴”义探赜一隅 [Dilogía ambigua: Una breve investigación en el Xing de poesía]”, 中国文学网 [Página Web de la Literatura del Chino], disponible en: http://www.literature.org.cn/ article. aspx?id=6659

Osorio, Mariana (2012), “¿Por qué el chino es uno de los idiomas más difíciles?”, Guioteca, febrero 10, disponible en: http://www.guioteca.com/ cultura-china/por-que-el-chino-es-uno-de-los-idiomas-mas-dificiles/

Wang, De Hua (2012), “刘禹锡的爱情诗如何运用谐音双关的” [Cómo utilizó Liu Yuxi la dilogía del chino en sus poemas de amor]”, Enciclopedia de la Enseñanza del Chino, marzo 22, disponible en: http://yuwenjiaoyu.baike. com/article-237049.html

Yu, Yue (2009), “中国出版首部《现代汉语同音词词典》 (El primer diccionario de palabras homófonas de China)", Página de China, septiembre 25, disponible en: http://www.china.com.cn/book/txt/2009-09/25/ content_18598203.htm

Zhu, Fu Wang (2011), “歇后语 [Xie Hou Yu de las Palabras Homófonas]”, 祝 福网 [Página Web de Palabras de Buen Deseo], agosto 28, disponible en: http://www.xzhufu.com/xiehouyu/13200.html 